\title{
Kontribusi Kekuatan Otot Tungkai dan Kelenturan Pinggang Terhadap Hasil Bantingan Kayang Dalam Olahraga Gulat
}

\section{Contribution Of Leg Muscle Strength and Flexibility Of The Waist To The Ability To Throw Kayang In Wrestling}

\author{
Bayu Adhitiya.B ${ }^{1}$, Arwin ${ }^{2}$, Bogy Restu Ilahi ${ }^{3}$ \\ ${ }^{123}$ Prodi Penjas, FKIP, Universitas Bengkulu, Kota Bengkulu, 38223, Indonesia
}

\begin{abstract}
Abstrak
Penelitian ini bertujuan untuk mengetahui kontribusi kekuatan otot tungkai dan kelenturan pinggang terhadap hasil bantingan kayang dalam olahraga gulat. Penelitian ini dilakukan di sasana gulat kota Bengkulu pada bulan Februari 2021. Metode penelitian yang digunakan metode kuantitatif, penelitian ini dengan sampel 22 orang Atlet gulat Bengkulu yang diambil dengan teknik total sampling. Adapun hasil data $\mathrm{r}$ hitung $=0.47>\mathrm{r}$ tabel $=0,423$ artinya terdapat kontribusi yang berarti antara $\mathrm{X} 1$ dengan $\mathrm{Y}$ dalam hitungan persen $22,09 \%$. Hasil data $r$ hitung $=0,70>\mathrm{r}_{\text {tabel }}=0,423$ artinya terdapat kontribusi yang berarti antara X2 dengan $\mathrm{Y}$ dengan hitungan persen 49,9\%. dan hasil data $\mathrm{r}_{\text {hitung }}=0,72>$ $\mathrm{r}_{\text {tabel }}=0,423$ artinya terdapat kontribusi yang berarti antara $\mathrm{X} 1$, dan $\mathrm{X} 2$ dengan $\mathrm{Y}$ dengan hitungan persen $51,85 \%$. Sehingga dapat disimpulkan bahwa ada kontribusi antara kekuatan otot tungkai dan otot kelenturan pinggang terhadap hasil bantingan kayang $73,3 \%$ dan mendukung lainya $24,7 \%$.
\end{abstract}

Kata kunci: Kekuatan Otot Tungkai, Kelenturan Pinggang, Bantingan Kayang

Abstract

This study aims to determine the contribution of leg muscle strength and waist flexibility to kayang dings in wrestling. This research was conducted in the wrestling gym of Bengkulu city in February 2021. The methods research used quantitative methods, this research was objectively or what there were with a sample of 22 athletes wrestling Bengkulu who were taken with a total sampling technique. The results of the data $r$ count $=0.47>r$ table $=0.423$ means that there is a contribution which means between X1 and $Y$ in a percentage of $22.09 \%$. The result of data $r$ count $=0.70>$ rtabel $=0.423$ means that there is a significant contribution between $X 2$ and $Y$ with a percent count of $49.9 \%$. and the results of the data rhitung $=0.72>$ rtabel $=0.423$ means that there is a significant contribution between X1, and X2 with Y with a percent count of $51.85 \%$. So it can be concluded that there is a contribution between leg muscle strength and waist flexibility to the results of kayang dings $73.3 \%$ and other supports $24.7 \%$.

Keywords: leg muscle strength, waist flexibility, kayang kick. 


\section{PENDAHULUAN}

Olahraga merupakan kegiatan aktifitas fisik yang di lakukan secara terstruktur dan berulang-ulang yang memiliki tujuan untuk mencapai kebugaran jasmani. Di Indonesia Olahraga banyak sekali jenis Olahraga yang diminati Masyarakat diantaranya Olahraga Tradisional, Olahraga kesehatan, dan Olahraga prestasi.

Ada banyak olahraga berprestasi di Indonesia salah satunya olahraga gulat. Banyak pertandingan di olahraga gulat mulai dari daerah, Nasional maupun Internasional. Contohnya seperti kejuaraan daerah, kejuaraan Nasional, pekan Olahraga pelajar, pekan Olahraga Nasional, Sea Games, Asian Games dan masih banyak lagi. dalam kejuaran ini ada juga tingkat-tingkatannya, seperti dari daerah ke Nasional, Nasional ke Internasional.

Olahraga gulat merupakan olahraga individu yang identik dengan dua orang pegulat saling berhadapan dan saling menyerang satu sama lain. dari kedua pegulat berada pada posisi kedua bahu menempel pada matras. Banyak teknik yang di pelajari oleh atlet gulat untuk menjatuhkan lawan, tergantung gaya yang sedang di pakai oleh pegulat.ada dua gaya dalam pertandingan gulat yaitu gaya bebas dan gaya greco-roman.

Pada penelitian ini penulis akan membahas tentang penelitian olahraga gulat yaitu teknik bantingan kayang (back arch) menurut buku Mark Mysnyk, MD (2010:124)"gerakan melengkung punggung atau bantingan kayang (back arch) mencakup mengangkat lawan kebelakang, gerakan ini digunakan beberapa lemparan, khususnya lemparan gaya bebas.gerakan melengkungkan pinggang atau bantingan kayang bisa digunakan saat didepan,belakang,ataupun samping lawan"

Pada posisi teknik bantingan kayang ada banyak faktor yang peneliti perhatikan, selain dari gerakkan kayang menggunakan otot pingang yang lentur, ada juga faktor tangkapan pinggang lawan menggunakan kedua tangan, ada juga fakor kekuatan otot tungkai kaki yang berfungsi sebagai daya lecut proses bantingan terhadap lawan yg sedang dibanting sehingga membuat lawan teranggkat ke atas membentuk garis lingkar. Proses yang sistematis ini membuat peneliti sangat tertarik meneliti apa saja faktor yang mempengaruhi keberhasilan teknik bantingan kayang ini karna point yang di dapatkan adalah point tertinggi 
pada perolehan hasil semua teknik pada gulat baik gulat gaya greggo roman maupun gulat gaya bebas.

Dengan harapan point yang tingggi maka pegulat mengaggap teknik ini teknik yang sangat menarik di pelajari, diketahui bahwa mempengaruhi bahwa keberhasilan pegulat, diantaranya pegulat kurang percaya diri dalam melakukan bentingan, kurangnya kekuatan otot tungkai, kurang lenturnya otot pinggang, kurangnya pressan dalam memegang lawan, dan butuh keseimbangan dalam melakukan bantingan kayang. Hal inilah yang dikemukakan oleh pelatih senior gulat Bengkulu, Edy Santoso dan di dampingi Subki.

Ketertarikan peneliti untuk melakukan penelitian mengenai kekuatan otot khususnya kekuatan otot tungkai atas dan kelenturan pinggang dengan harapan pelatih lebih memberikan bentuk latihan yang lebih spesifik guna keberhasilan teknik bantingan kayang. Hal ini yang menjadi fokus peneliti untuk meneliti "Kontribusi kekuatan otot tungkai dan kelenturan pinggang terhadap kemampuan bantingan kayang dalam olahraga gulat pada atlet Gulat Provinsi Bengkulu".

\section{METODE}

Metode penelitian pada dasarnya merupakan cara ilmiah untuk mendapatkan data dengan tujuan dan kegunaan tertentu. Berdasarkan hal tersebut dapat empat kata kunci yang perlu di perhatikan yaitu ,cara ilmiah, data, tujuan, dan kegunaan sugiyono (2011:2). Metode penelitian yang penulis gunakan dalam penelitian ini adalah korelasi, yang ingin melihat hubungan antara variabel bebas dan variabel terikat. Penelitian ini dilaksanakan pada Penelitian ini di lakukan pada bulan Oktober 2020, tempat penelitian ini di lakukan di Gedung Sasana gulat Provinsi Bengkulu yang beralamatkan di asrama PPLP Bumi Ayu.

Untuk mengumpulkan data dari sempel penelitian di butuhkan alat yang di sebut instrumen. Arikunto, (2006:160) menjelaskan instrumen adalah alat yang di gunakan oleh peneliti dalam mengumpilkan data agar lebih mudah dan hasilnya lebih baik, dalam arti lebih cepat, lengkap dan sistematis sehingga lebih mudah di peroleh. Adapun alat ukur yang penulis gunakan dalam penelitian tes terdiri dari 3 item tes, untuk mengambilan data dalam penelitian ini,penulis menggunakan alat tes untuk mengetahui konstribusi kekuatan otot tungkai atas,kelenturan pinggang 
terdapat efektifitas teknik bantingan kayang pada olahraga gulat, leg dynamometer untuk mengukur otot tungkai atas sikap kayang untuk kelenturan pinggang dan teknik banting kayang dilihat dari kesempurnaan gerakan dengan menggunakan jari. Teknik analisis data menggunakan uji normalitas, linieritas korelasi berganda dan uji kontribusi

\section{HASIL}

\section{Hasil Tes Kekuatan Otot Tungkai}

Dari hasil pengukuran kekuatan otot tungkai yang dilakukan terhadap Atlet Gulat Pengprov PGSI Propinsi Bengkulu didapat skor tertinggi 65 dan skor terendah 26, berdasarkan data kelompok tersebut rata-rata hitung (mean) 48.04 dan simpangan baku 9.36. Distribusi kategori kekuatan otot Tungkai Atlet Gulat Pengda PGSI Propinsi Bengkulu dapat dilihat pada tabel berikut:

Tabel. 1. Distribusi Frekuensi Hasil Tes Kekuatan Otot Tungkai

\begin{tabular}{ccc}
\hline Hasil Test & Frekuensi Absolut & Frekuensi Relatif (\%) \\
\hline $26-33$ & 1 & 4,55 \\
$34-41$ & 5 & 22,73 \\
$42-49$ & 6 & 27,27 \\
$50-57$ & 6 & 27,27 \\
$58-65$ & 4 & 18,18 \\
Jumlah & $\mathbf{2 2}$ & $\mathbf{1 0 0}$ \\
\hline
\end{tabular}

Dari data tabel 1 dapat disimpulkan bahwa dari 22 Atlet Gulat Pengprov PGSI Propinsi Bengkulu sebanyak 1 orang atlet (4.54\%) memilki kategori nilai 26-33 dan 5 orang atlet (22,73\%)dan memiliki kategori nilai 3441 dan sebanyak 6 orang atlet $(27,27 \%)$ memiliki kategori nilai $42-49$ dan sebanyak 6 orang atlet $(27,27 \%)$ memiliki kategori nilai 50-57 dan sebanyak 4 orang atlet $(18,18 \%)$ memiliki kategori nilai 58-65. 
Untuk lebih jelasnya lagi dapat dilihat pada grafik berikut:

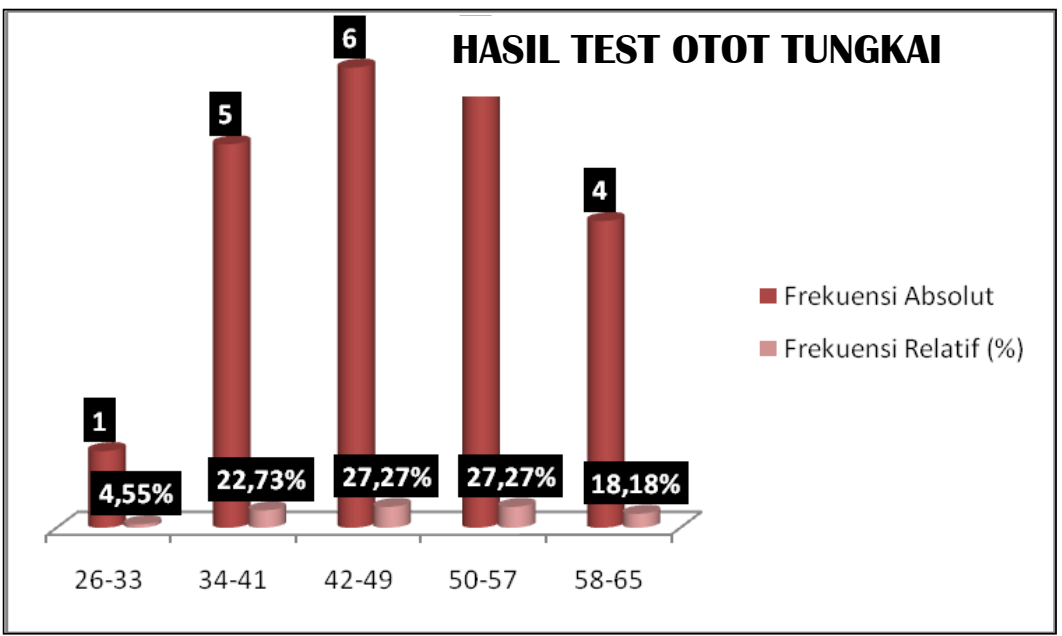

Gambar 1 Histogram Distibusi Variabel Kekuatan Otot tungkai

\section{Hasil Tes Kelenturan Pinggang}

Dari hasil tes kelenturan pinggang yang dilakukan terhadap Atlet Gulat Pengprov PGSI Propinsi Bengkulu didapat skor tertinggi 60 dan skor terendah 21, berdasarkan data kelompok tersebut rata-rata hitung (mean) 44,1 dan simpangan baku 14,8. Distribusi kategori kekuatan otot Tungkai Atlet Gulat Pengda PGSI Propinsi Bengkulu dapat dilihat pada tabel berikut:

Tabel. 2 Distribusi Frekuensi Hasil Tes Kelenturan Pinggang

\begin{tabular}{ccc}
\hline Hasil Tes & Frekuensi Absolut & Frekuensi Relatif (\%) \\
\hline $21-28$ & 6 & 27.27 \\
$29-36$ & 3 & 13.64 \\
$37-44$ & 0 & 0.00 \\
$45-52$ & 1 & 4.55 \\
$53-60$ & 12 & 54.55 \\
Jumlah & 22 & 100 \\
\hline
\end{tabular}

Dari data tabel 2 dapat disimpulkan bahwa dari 22 Atlet Gulat Pengprov PGSI Propinsi Bengkulu sebanyak 6 orang atlet $(27,27 \%)$ memiliki kategori nilai 21-28. sebanyak 3 orang atlet (13.64\%) memilki kategori nilai 2936dan 0 orang atlet $(0,00 \%)$ dan memiliki kategori nilai 37-44dan sebanyak 1 orang atlet (4.55\%) memiliki kategori nilai 45-52 dan sebanyak 12 orang atlet 
Bayu Adhitiya.B, Arwin, Bogy Restu Ilahi

Kontribusi Kekuatan Otot Tungkai dan Kelenturan Pinggang Terhadap Hasil Bantingan Kayang dalam Olahraga Gulat

(54.55\%) memiliki kategori nilai 53-60. Untuk lebih jelasnya lagi dapat dilihat pada grafik berikut :

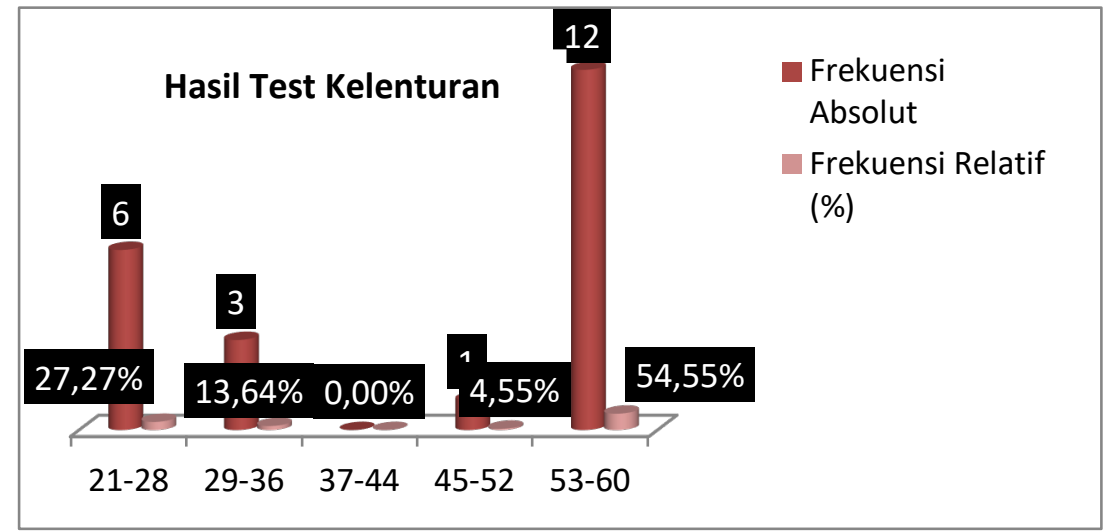

Gambar 2 Histogram Distribusi Skor Variabel Kelenturan Pinggang

\section{Hasil Tes Kemampuan Bantingan Kayang}

Dari hasil pengukuran kemampuan bantingan kayang yang dilakukan terhadap Atlet Gulat Pengprov PGSI Propinsi Bengkulu didapat skor tertinggi 62 dan skor terendah 31, berdasarkan data kelompok tersebut rata-rata hitung (mean) 49.2 dan simpangan baku 9,15 Distribusi Kemampuan Bantingan Kayang Atlet Gulat Pengda PGSI Propinsi Bengkulu dapat dilihat pada tabel berikut:

Tabel 3 Distribusi Frekuensi Hasil Tes Kemampuan Bantingan Kayang

\begin{tabular}{ccc}
\hline Hasil Test & Frekuensi Absolut & Frekuensi Relatif (\%) \\
\hline $31-37$ & 4 & 18.2 \\
$38-44$ & 0 & 0 \\
$45-51$ & 9 & 40.9 \\
$52-58$ & 5 & 22.7 \\
$59-65$ & 4 & 18.2 \\
Jumlah & 22 & 100 \\
\hline
\end{tabular}

Dari data tabel 3 dapat disimpulkan bahwa dari 22 Atlet Gulat Pengprov PGSI Propinsi Bengkulu sebanyak 4 orang atlet (18.2\%) memilki kategori nilai 31-37 dan orang atlet (0\%) dan memiliki kategori nilai 38-44 dan sebanyak 9 orang atlet (40,9\%) memiliki kategori nilai 45-51 dan sebanyak 5 
orang atlet $(22,7 \%)$ memiliki kategori nilai $52-58$ dan sebanyak 4 orang atlet $(18,2 \%)$ memiliki kategori nilai 59-65. Untuk lebih jelasnya lagi dapat dilihat pada grafik berikut

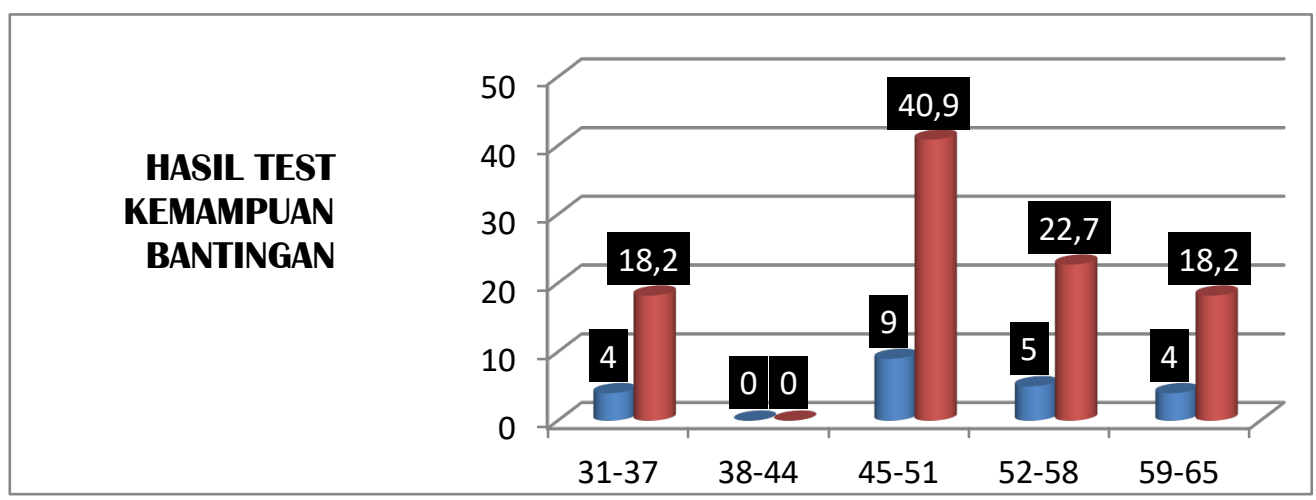

Gambar 3 Histogram Distribusi Skor Variabel Kemampuan Bantingan Kayang

\section{PEMBAHASAN}

\section{Hubungan Antara Kekuatan Otot Tungkai dengan Kemampuan Bantingan Kayang dalam olahraga gulat.}

Berdasarkan hasil analisis yang dikemukakan dan dari hasil pengujian hipotesis ternyata diterima kebenarannya.Ada hubungan yang signifikan antara kekuatan otot tungkai dengan Kemampuan Bantingan Kayang dalam olahraga gulat.Semakin kuat otot tungkai, maka semakin baik pula Kemampuan Bantingan Kayang. Menurut Soedarminto (2008:79) mengemukakan bahwa : "tungkai terdiri dari tungkai atas dan tungkai bawah, tungkai atas terdiri dari pengkal paha sampai lutut, sedangkan tungkai bawah terdiri atas lutut sampai kaki." Kekuatan (strength) menurut Bompa yang dikutip Hendri Irawadi adalah Kekuatan kemampuan otot dan syaraf untuk mengatasi beban internal dan eksternal (2011:48). Otot tungkai adalah otot dari tungkai bagian atas dan otot tungkai bagian bawah. Jadi kekuatan otot tungkai adalah kemampuan otot tungkai untuk menggerakkan tubuh sendiri, lawan, alat dan juga mengatasi suatu beban melalui kerja otot tungkai untuk mengatasi beban internal dan eksternal. Dari hasil pengujian hipotesis antara kekuatan otot tungkai dengan Kemampuan Bantingan Kayang, kontribusi kekuatan otot tungkai terhadap Kemampuan Bantingan Kayang adalah sebesar $22,09 \%$. 


\section{Hubungan Kelenturan Pinggang Terhadap Kemampuan Bantingan Kayang Dalam Olahraga gulat}

Berdasarkan hasil analisis yang dikemukakan dan dari hasil pengujian hipotesis ternyata diterima kebenarannya. Ada hubungan yang signifikan antara kekuatan otot tungkai terhadap Kemampuan Bantingan Kayang dalam olahraga gulat namun disini dinyatakan bahwa hubungan yang terjadi bernilai positif dimana semakin tinggi nilai kelenturan pinggang maka akan semakin baik kemampun bantingan kayang. Dari hasil penguji hipotesis antara kelenturan pinggang dengan hasil bantingan kayang adalh sebesar 49\%

\section{Hubungan Antara Kekuatan Otot Tungkai dan Kekuatan Otot} Tungkai Dengan Kemampuan Bantingan Kayang dalam olahraga gulat.

Berdasarkan hasil analisis yang dikemukakan dan dari hasil pengujian hipotesis ternyata hipotesis yang diajukan diterima kebenaranya ada hubungan yang positif dan signifikan antar Kekuatan Otot Tungkai dan Kelenturan Pinggang dengan Kemampuan Bantingan Kayang. Berdasarkan hasil koofesien korelasi tingkat hubungannya berada pada tingkat hubungan yang kuat. Otot tungkai memiliki banyak otot yang terdapat pada tungkai. Menurut Gardner dkk dalam Ridwan Maulana (2010: 10-11), Seperti halnya anggota tubuh bagian atas, Anggota tubuh bagian bawah di hubungkan dengan badan oleh sebuah sendi yang terdiri dari tiga bagian, yaitu tungkai atas, dan tungkai bawah.

Faktor penentu sempurna atau tidaknya teknik bantingan tergantung pada seberapa kuat otot tungkai aras mengangkat beban, serta seberapa lenturnya pinggang untuk mengatur posisi ideal. Pinggang adalah anggota badan bagian belakang yang terdirI dari lima tulang yang biasa disebut tulang pinggang atau dengan bahasa ilmiahnya vertebla lumbal, jadi penulis mengambil pengetian di maksud yaitu kemampuan otot tungkai untuk mengakat, sedangkan kelenturan pinggang berfungsi untuk mengayunkan seluruh anggota badan untuk di lempar ke belakang dan posisi tubuh seperti kayang. Dari hasil pengujian hipotesis variabel antara kekuatan otot tungkai dan kekuatan otot tungkai terhadap 
Kemampuan Bantingan Kayang, kontribusi Kekuatan Otot Tungkai dan Kekuatan Otot Tungkai Dengan Kemampuan Bantingan Kayang adalah sebesar 51,84\%.

Berdasarkan pemaparan diatas, dapat disimpulkan bahwa kontribusi terbesar antara variabel terdapat pada Kekuatan Otot Tungkai dan Kelenturan Pinggang Dengan Kemampuan Bantingan Kayang $\left(\mathrm{X}_{1}\right.$ dan $\mathrm{X}_{2}$ terhadap $\left.\mathrm{Y}\right)$ adalah sebesar $\mathbf{5 1 , 8 4 \%}$ dan $\mathbf{4 8 , 1 6 \%}$ di pengaruhi oleh faktor lainya.

\section{KESIMPULAN}

1. Terdapat hubungan yang positif dan signifikan kekuatan otot tungkai dengan Hasil Bantingan Kayang pada Atlet gulat provinsi Bengkulu. Hal ini dibuktikan dengan $r_{\text {hitung }}=0,47>r_{\text {tabel }}=0,423$ dengan taraf signifikansi $\alpha=$ 0,05 didapat $. \mathrm{t}_{\text {hitung }}=2,3873>\mathrm{t}_{\text {tabel }}=2,0859$. Hal ini berarti kekuatan otot tungkai sangat mempengaruhi hasil dari Hasil Bantingan Kayang.

2. Terdapat hubungan yang positif dan signifikan kelenturan pinggang dengan bantingan kayang pada Atlet gulat provinsi Bengkulu. Hal ini dibuktikan dengan $r_{\text {hitung }}=0,70>r_{\text {tabel }}=0,423$ dengan taraf signifikansi $\alpha=0,05$ didapat $\mathrm{t}_{\text {hitung }}=6.1352>\mathrm{t}_{\text {tabel }}=2,08596$ hal ini berarti tingkat kelenturan pinggang bepengaruh positif atas hasil bantingan kayang arttinya semakin baik kelenturan pinggang akan menghasilkan bantingan kayang yang baik.

3. Ada kontribusi antara kekuatan otot tungkai (x1) dan kelenturan pinggang (x2) terhadap hasil bantingan kayang (Y) pada atlet gulat Bengkulu yaitu sebesar 51,84,\%. Hal ini membuktikan bahwa kekuatan otot tungkai (x1) dan kelenturan pinggang $\left(\mathrm{x}_{2}\right)$ terhadap hasil bantingan kayang $(\mathrm{Y})$ yang diberikan pada tingkat distribusi sedang dan $48,16 \%$ dipengaruhi oleh faktor lainnya.

\section{REFERENSI}

Chu, D,A, Myer,G, D. (2013). Plyometrics. United States of America: Human Kinetics.

Hasanah, M. (2013). Pengaruh Latihan Pliometrik Depth Jump Dan Jump To Box Terhadap Power Otot Tungkai Pada Atlet Bolavoli Klub Tugumuda Kota Semarang (Doctoral dissertation, Universitas Negeri Semarang).

Pujianto, D. \& Insanistyo. (2013). Bahan Ajar Dasar-Dasar Penelitian Pendidikan Jasmani. Bengkulu: FKIP Universitas Bengkulu. 
Soedarminto, Lutan, R. 2008. Manusia dan Olahraga. Bandung : ITB FPOK UPL

Rizaldianto, D. (2016). Kondisi Kapasitas Fisik (Kekuatan, Daya Tahan, Kecepatan, dan Daya Ledak) dan Kadar Hemoglobin Atlet Balap Sepeda Jalan Raya ISSI Kota Semarang Tahun 2016. Universitas Negeri Semarang.

Raibowo, S.,\& Nopiyanto,Y. E. (2020). Evaluasi Pembelajaran Pendidikan Jasmani Olahraga \& Kesehatan pada SMP Negeri Se-Kabupaten Mukomuko melalui Pendekatan Model Context, Input, Process \& Product (CIPP). Jurnal Pendidikan Kesehatan Rekreasi, 6(2), 146-165.

Maulana, Ridwan (2010). Kekuatan Power Tungkai, Kekuatan Otot Tungkai Dan Kelincahan Siswa Dalam Memgikuti Ekstrakulikuler Sepak Bola Dan Futsa Di Smp Negeri 3 Gadean , 3(4)10-11

Sihombing, S. (2019). Hubungan Panjang Tungkai Dan Daya Ledak Otot Tungkai Dengan Hasil Lari Sprint 100 Meter. Kinestetik: Jurnal Ilmiah Pendidikan Jasmani, 3(2), 256-261.

Sugiyono, (2018). Metode Penelitian Kuantitatif, Kualitatif Dan R\&d. Bandung : Alfabeta CV

Suherman, (2018). Buku Guru Pendidikan Jasmani, Olahraga Dan Kesehatan, Jakarta : PT Gramedia.

Widiastuti, (2011). Tes dan Pengukuran Olahraga. Jakarta: PT Bumi Timur Jaya.

Yarmani, Y. (2017). Pengaruh Latihan Shooting Drills Terhadap Hasil Three Point Shooting Atlet Putra Klub Bola Basket King Spark Kota Bengkulu. Kinestetik: Jurnal Ilmiah Pendidikan Jasmani, 1(2), 75-79. 